\title{
A Stand Density Diagram for Eucalyptus Plantations in Guangxi, China
}

\author{
Roger A Williams* \\ School of Environment and Natural Resources, The Ohio State University, USA
}

Submission: February 08, 2017; Published: March 242017

"Corresponding author: Roger A Williams, School of Environment and Natural Resources, The Ohio State University, USA, Tel: 1-614-688-4061; Fax: 1-614-292-7432; Email: williams.1577@osu.edu

\begin{abstract}
A stand density management diagram based on stand density index has been developed for use with eucalyptus (Eucalyptus urophylla $\times$ E. grandis) plantations in the province of Guangxi, south China. Using $\mathrm{dbh}$ of $10 \mathrm{~cm}$ as the reference diameter, the maximum stand density index was defined as 2800 trees ha $^{-1}$. Based on crown projection ratios it was discovered that the point of crown closure occurs at a stand density index of 925 . While the data did not allow a specific calculation of the density where self-thinning begins, examination of other published data and crown projection ratio, it would appear that self-thinning occurs at a stand density index of 2090 to 2200 , or $75 \%$ to $79 \%$ of the maximum density. An interpretation of the diagram is presented.
\end{abstract}

Keywords: Density; Management; Eucalyptus; Guangxi; China

\section{Introduction}

Rapid economic growth in China over the past decade has created a timber deficit to exist in China's domestic timber supply. Subsequently, China has become the world's largest importer of logs and wood pulp, and the second largest importer of lumber and woodchips [1]. In 2014, the total of China's primary forest products imports accounted for approximately 10 percent of the global production of industrial round wood. In response to this timber deficit China continues to implement policy measures and land tenure reforms that will increase the quantity and quality of its forests. China's State Forest Administration (SFA) is attempting to increase its domestic timber supply from the 180 million $\mathrm{m}_{3}$ /year recorded in 2010 to a projected 300 million $\mathrm{m} 3$ / year by 2020 [2]. During this period of time the SFA expects the industrial demand for wood will increase to 467 million $\mathrm{m}_{3} /$ year, creating a deficit of 167 million $\mathrm{m}_{3}$ /year. In spite of the slower economic growth over the past few years it is therefore expected that the continued high timber deficit will continue to exist, with the expectations that China's timber and forest products imports to increase by 60 million cubic meters by 2025 or 12 to 13 percent of the global timber harvest [1]. In efforts to reduce this timber deficit, China has been rapidly expanding it forest area.

Approximately 129 million hectares (62\%) are primary and naturally regenerated forests, while 79 million hectares (38\%) are planted forests [2]. Accordingly, China now has the largest plantation area in the world, principally of fast-growing species, particularly eucalyptus. The total area of eucalyptus in China has grown from an estimated area of 670,000 hectares in the mid-1990s to 3.6 million hectares in 2011, to its present estimation of at least 4 million hectares [3-6]. These plantations occur primarily in Guangdong, Guangxi, Hainan Island, Yunnan, Sichuan and Fujian provinces with more than 1.4 million hectares in Guangxi alone [7]. The eucalyptus clone, Eucalyptus urophylla $\times$ E. grandis, selected by Dongmen Forest Farms in Guangxi [8], is the species most widely planted in south China because of its adaptability and stable rapid growth, producing as much as $30 \mathrm{~m} 3 / \mathrm{ha} / \mathrm{yr}$ [9].

However, proper management of this species on a large scale is necessary to maintain its productivity if is going to contribute to reducing China's timber deficit. Much of forest management involves to some degree the control of forest density $[10,11]$, for it is through density manipulation that forest productivity can be increased and product goals achieved. Density management diagrams have been developed in a variety of forms to facilitate the decisions regarding density control. These diagrams present graphically the relationship among tree size, stand density, competition, volume and site occupancy, giving guidance to the proper densities to be maintained to meet certain management objectives [10,12-14]. While some management goals may be to maximize the total volume production, other goals might be to 
maximize individual tree volume production. Proper control of stand density requires some knowledge of what are the upper and lower limits of stocking. Knowledge of upper stocking limits is necessary to ensure full site occupancy without becoming too dense to achieve management goals. Knowledge of lower limits is necessary to promote individual tree growth and still utilize all available growing space [15].

Eucalyptus species will respond favorably to both noncommercial and commercial thinnings soon after crown closure occurs, with as much as a $60 \%$ increase in growth (Ronggui et al. 2003). Even though eucalyptus species display very rapid height growth, the majority of the thinning responses occur in increased diameter increment (Pinkard and Neilson 2003). In most eucalyptus plantations, if saw log and veneer-quality products are desired, then thinnings will be necessary. The question becomes then to what density should plantations be thinned to acquire the quality of products needed and provide the best rate of return (Pinkard and Neilson 2003) [16]. But even if the objectives were to manage for fiber, there still exists optimal densities to maintain these forests such that health and vigor of trees are not sacrificed and high total volumes are achieved. It was therefore the objective of this paper to develop and present a density management diagram for eucalyptus (Eucalyptus urophylla $x$ E. grandis) plantations in Guangxi to better facilitate the approximation of appropriate densities to manage plantations for different goals. The actual manipulation of stand density is easy, but the best density level for thinning a stand is more difficult to determine without guidance.

Table 1: Summary of eucalyptus (Eucalyptus urophylla x E. grandis) forest attributes on plots from which data was collected near Liuzhou, Guangxi, China.

\begin{tabular}{|c|c|c|c|c|c|c|c|c|c|}
\hline \multirow{2}{*}{ Age (yrs) } & \multirow{2}{*}{$\mathbf{N}^{\mathrm{a}}$} & \multicolumn{2}{|c|}{ Trees per ha } & \multicolumn{2}{|c|}{ Basal area $\left(\mathrm{m}^{2} / \mathrm{ha}\right)$} & \multicolumn{2}{|c|}{ Mean dbh $(\mathrm{cm})$} & \multicolumn{2}{|c|}{ Mean height (m) } \\
\hline & & Mean & Std & Mean & Std & Mean & Std & Mean & Std \\
\hline 1 & 6 & 1740 & 196.4 & 4.1 & 0.63 & 5.4 & 0.46 & 6.4 & 0.77 \\
\hline 2 & 9 & 1273 & 165.8 & 8.3 & 2.54 & 8.9 & 1.42 & 11.7 & 2.19 \\
\hline 3 & 6 & 1243 & 215.6 & 13 & 1.56 & 11.3 & 0.73 & 15 & 1.06 \\
\hline 4 & 6 & 1740 & 574.9 & 17.2 & 2.57 & 11.2 & 1.28 & 14.9 & 1.63 \\
\hline 5 & 9 & 1234 & 152.7 & 18.2 & 2.35 & 13.5 & 1.24 & 17.7 & 1.47 \\
\hline 10 & 3 & 447 & 261 & 21 & 6.29 & 23.7 & 7.44 & 26.4 & 6.78 \\
\hline 21 & 3 & 587 & 98.7 & 30.3 & 1.39 & 24.5 & 2.06 & 28.2 & 2.07 \\
\hline
\end{tabular}

${ }^{\mathrm{a}} \mathrm{N}=$ The number of sample plots.

The forest canopy becomes an important consideration in density management and therefore it was essential to collect information regarding tree crowns in these forests. Six to eight trees were selected on each sample plot for the purpose of measuring the crown dimensions-crown diameter and crown length. The crown diameter of these selected trees was measured by first locating the major crown axis and marking it on the

\section{Materials and Methods}

\section{Study area}

The study was performed on the forests of Guangxi EcoEngineering Vocational and Technical College located near the city of Liuzhou in the northeast section of Guangxi Province. The forest (approximately N24o29' latitude, E109o22' longitude) occupies 1,215 hectares and is comprised mostly of planted stands of Chinese fir (Cunninghamia lanceolata), Masson pine (Pinus massoniana) and the eucalyptus hybrid (Eucalyptus urophylla $x$ E. grandis). This region lies within the southeastern edge of the subtropical monsoon climate areas of China [17]. The mean annual temperature within the region is $21.1{ }^{\circ} \mathrm{C}$, with a maximum of $40.3{ }^{\circ} \mathrm{C}$ in the summer and $-1.5^{\circ} \mathrm{C}$ in winter. The average annual precipitation ranges from 1200 to $1500 \mathrm{~mm}$ with average relative humidity ranging from 80 to $84 \%$. The main geomorphic types are lower mountains and hills, characterized by rolling topography, which are dominated by moderately developed arenaceous shale red soils and strongly developed clay arenaceous shale red soils [18].

\section{Data collection}

Unthinned eucalyptus forests (Eucalyptus urophylla $x$ E. grandis) were sampled with three 0.05 ha circular plots in each forest and ranged in age from 1 to 21 years (Table 1). The aspect, slope percent, and slope position of each plot was recorded from the plot center. On each plot, the dbh was measured and recorded for each tree with the use of a d-tape to the nearest $0.1 \mathrm{~cm}$. 
Since bias is typically introduced with the clinometer, 12 trees that represent the range of tree sizes on sample plots were selected and felled to measure the actual total length (height) and length to live crown of the tree. These measured lengths was used to determine the standard error of the clinometer measurements, and applied to heights measured with the clinometer to achieve more accurate height measurements. Based on comparisons of height measurements from the clinometer with the measured lengths of the tree after they had been felled, a margin of measurement error of \pm 0.90 meters and \pm 1.68 meters was determined at $p=0.05$ for total height and height-to-live-crown, respectively.

Equations were developed from the measurement data of selected trees and were used to estimate the total height, height- to-live-crown, and crown diameter of all trees on plots based on the measured dbh. A model of the form:

$$
\mathrm{Y}=\mathrm{a}(\ln \mathrm{D})^{\mathrm{b}}
$$

Where $\mathrm{Y}=$ =ither total height, height to live crown, or crown diameter $(\mathrm{m}), \mathrm{D}=\mathrm{dbh}(\mathrm{cm})$ and $\mathrm{ln}=$ natural logarithm, was used to develop prediction equations. The model coefficients were estimated using the Non-Linear Procedure, Gauss-Newton method in SAS software, version 9.2 [19] and are presented in Table 2. Crown diameter was determined by finding the quadratic mean of the major and minor axis measurements. These equations were applied to all remaining trees for which field measurements of height and crown diameter were not recorded.

Table 2: Coefficients and statistics for the height and crown diameter models ${ }^{1}$ using $\mathrm{dbh}(\mathrm{cm})$ as the independent variable for eucalyptus (Eucalyptus urophylla $\times$ E. grandis) in northeast Guangxi Province, PR China.

\begin{tabular}{|c|c|c|c|c|c|c|c|}
\hline \multirow{2}{*}{$\begin{array}{c}\text { Dependent } \\
\text { Variable }^{2}\end{array}$} & \multirow{2}{*}{$\mathbf{N}$} & \multicolumn{2}{|c|}{ Equation Co-efficients } & \multirow[b]{2}{*}{ RMSE } & \multirow[b]{2}{*}{$\mathbf{R}^{2}$} & \multirow[b]{2}{*}{ F value } & \multirow[b]{2}{*}{$\operatorname{Pr}>\mathrm{F}$} \\
\hline & & a & b & & & & \\
\hline $\mathrm{H}^{\mathrm{t}}$ & 131 & 1.9227 & 2.3320 & 2.5020 & 0.9858 & 4490.2 & $<0.0001$ \\
\hline $\mathrm{H}^{\mathrm{lc}}$ & 96 & 1.2022 & 2.4266 & 3.5416 & 0.9486 & 867.5 & $<0.0001$ \\
\hline $\mathrm{D}^{\mathrm{cr}}$ & 96 & 1.0260 & 1.4077 & 0.7626 & 0.9696 & 1499.4 & $<0.0001$ \\
\hline
\end{tabular}

${ }^{1}$ Model: $Y=a(\ln D)^{b}$

where $Y=$ total height, height to live crown, or crown diameter $(\mathrm{m}), \mathrm{D}=\mathrm{dbh}(\mathrm{cm})$ and $\mathrm{ln}=$ natural logarithm.

${ }^{2}$ Dependent variables are defined as: $H^{t}=$ Total height $(m), H^{l c}=$ height to live crown $(m)$ and $D^{c r}=c r o w n$ diameter $(m)$

\section{Results}

The concept of a maximum tree size-stand density relationship has long been reported and studied with various species and quantifications of average plant size [20-24]. This concept basically describes a reciprocal change in average plant mass or size with change in plant number per unit area.

Reineke (1933) introduced a relationship for stands at full density of average tree size (average stand diameter) with plant number per unit area in the form:

$$
\log (\mathrm{N})=\mathrm{b}_{0}+\mathrm{b}_{1} \log (\mathrm{D})
$$

Where, $\mathrm{N}$ is trees per acre, $\mathrm{D}$ is the average stand diameter (diameter at breast height of a tree with the average basal area), $\log$ is the base 10 logarithm, and b0 and b1 are coefficients to be estimated. Reineke further used this relationship to quantify a stand-density index (SDI) by comparing stands of different tree sizes and stand densities by using a common average diameter of $10 \mathrm{in.} \mathrm{A} \mathrm{major} \mathrm{advantage} \mathrm{of} \mathrm{this} \mathrm{size-density} \mathrm{index} \mathrm{is} \mathrm{that} \mathrm{it} \mathrm{is}$ independent of site quality and stand age [25]. Equation (1) was used to determine the stand density index and the maximum tree size-density line for the eucalyptus plantations. The b0 and b1 coefficients were estimated from the data using linear regression techniques, which produced the equation:

$$
\ln (\mathrm{N})=4.9003-1.5858 \log (\mathrm{D})
$$

with an $\mathrm{R}^{2}$ value of 0.8890 and the intercept and slope coefficients were significant at the $\mathrm{P}=0.05$ level. Data from eucalyptus stands that were four years of age and older were used to define this relationship as the assumption in Reineke's equation was applicable to stands of full density. Accordingly, it was safe to assume that by the time eucalyptus stands reached four years of age they had attained full density.

A reference diameter of $10 \mathrm{~cm}$ was chosen as this diameter fell in the middle of the range of diameters found in stands one year to five years of age. The majority of stands within this region are placed on five to six year rotations. Therefore, if $\mathrm{D}$ has a value of $10 \mathrm{~cm}$, then $\mathrm{N}$ becomes SDI:

$$
\log (\mathrm{SDI})=4.9003-1.5858 \log (10)
$$


Since it is assumed that the slope $\left(b_{1}\right)$ of Equation (3) remains constant for each SDI value but the intercept $\left(b_{0}\right)$ changes, then Equation (4) was solved in terms of the b0 coefficient to produce the equation:

$$
4.9003=\log (\mathrm{SDI})+1.5858 \log (10)
$$

Equation (5) was substituted into Equation (3) and solved for SDI:

$\log (\mathrm{SDI})=-4.9003+1.5858 \log (\mathrm{D})+\log (\mathrm{N})$

Equation (6) was used to position a maximum average tree size-density line for the data which was determined to be at a stand density index of 2800 (Figure 1). This defines the first critical stand density boundary described in this paper.

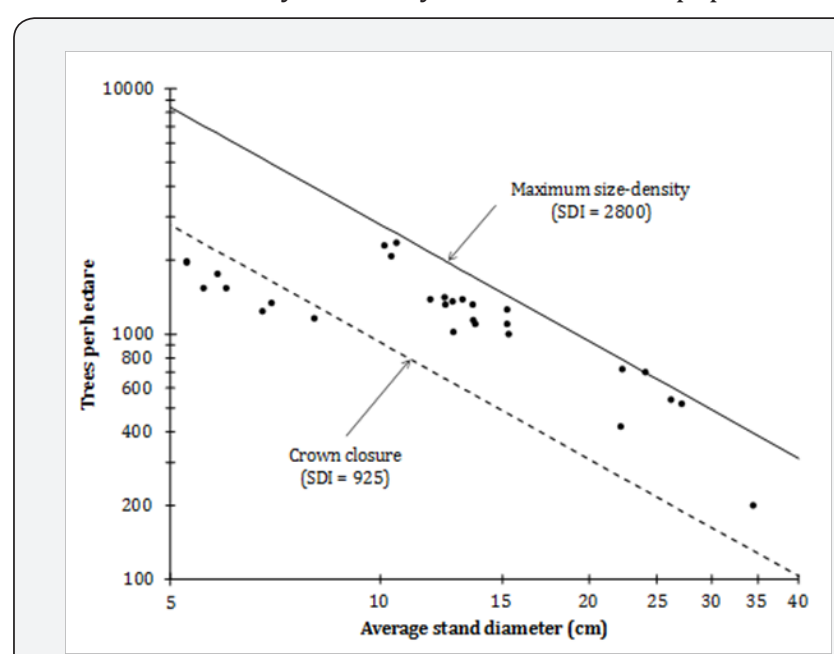

Figure 1: The maximum tree size-density and point of crown closure for eucalyptus (Eucalyptusurophylla $x$ E grandis) plantations in Guangxi, China.

The crowns of trees are an important consideration in density management and control of forest productivity as the essential function of the forest canopy is to allow plants to capture energy for photosynthesis, and to facilitate the production of reproductive organs such as flowers, fruits and seeds. The health and condition of the forest canopy, and tree crowns, directly influences the growth and productivity of forests. It is important to know the age or density at which diameter growth in a stand will become reduced due to competition. One of the first components of the tree to be impacted by the onset of competition is the tree crown, which ultimately affects the diameter increment of the tree. Therefore knowing at what age or density crown closure occurs and tree competition begins is critical to the understanding of proper density management in eucalyptus forests.

If it is assumed that a tree with a given crown diameter, DC, would require at least DC $^{2}$ amount of space to grow free of competition based on crown diameter, hence referred to as crown projection area. Theoretically, as stands initiate and continue to grow, crown closure occurs when the total crown projection area is equal the total ground area being occupied by trees, or, a ratio of 1:1 (1.0). For example at the point of crown closure on a hectare we would expect the total crown area projected onto the ground to be equal to $10000 \mathrm{~m} 2$, and hence 10000: 10000, or 1.0. Prior to crown closure, the ratio, hence crown projection ratio (CPR), is less than 1.0, but after crown closure is reached, the ratio becomes greater than 1.0 , competition continues and mortality occurs. The crown projection ratio will become $>1.0$ as the crowns begin to fill-in gaps between trees, causing the average diameter of the crown to increase.

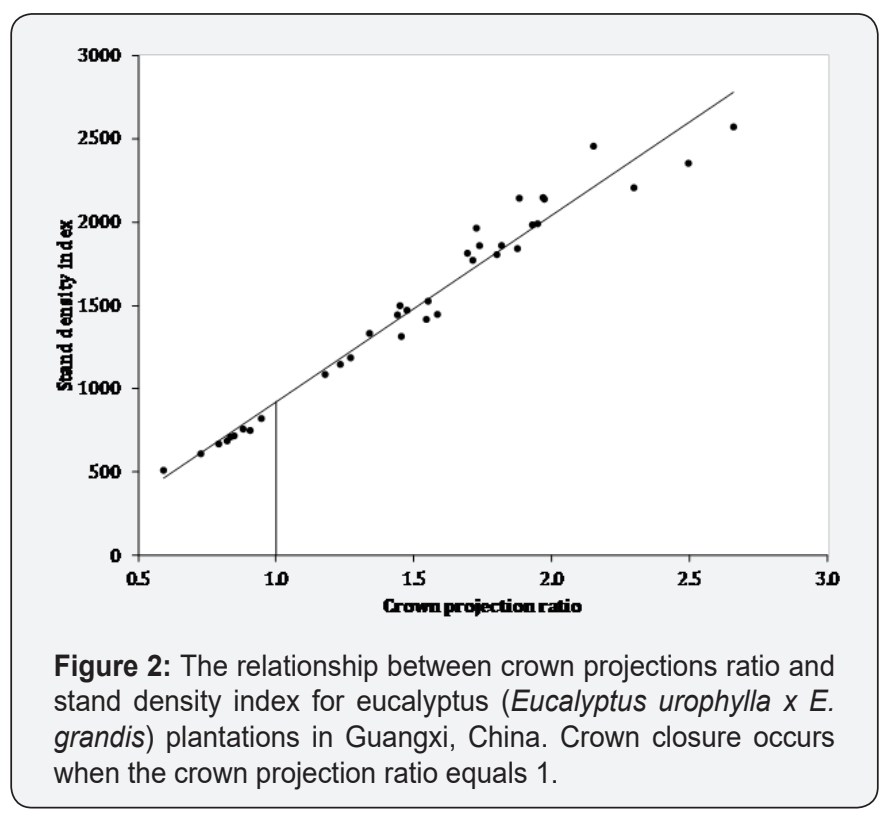

It was found that the relationship between SDI and CPR produced the following (Figure 2):

$$
\mathrm{SDI}=-193.9687+1117.8944(\mathrm{CPR})
$$

with an $\mathrm{R}^{2}$ value of 0.9646 and all coefficients significant at the $\mathrm{P}=0.05$ level. Assuming that crown closure occurs when the crown projection ratio (CPR) equals 1.0 then crown closure occurs when an SDI of approximately 925 is attained. Equation 6 was used to plot a line where SDI equals 925 on Figure 1. This defines a second critical boundary described in this paper. The data points below crown closure are some of the very young stands ( 1 and 2 years) that have not attained crown closure. The average crown closure of these plots as measured with a densiometer is $83 \%$ with an average crown projection ratio of 0.81 . An SDI of 925 represents a density that is $33 \%$ of the maximum density found in this study. This falls within the range of crown closure densities found or used, for other species, which range from $18 \%$ to $50 \%$ [14,23-26].

Equation 6 was used to plot a series of lines in increments of 2000 SDI on a log-log scale to produce the density management diagram (Figure 3). Because of difficulty that is sometimes encountered by using a diagram, a table showing the SDI values for corresponding average stand diameters and number of trees per acre was produced (Table 3). 
Table 3: Stand density index (base dbh $10 \mathrm{~cm}$ ) for eucalyptus plantations in Guangxi, China.

\begin{tabular}{|c|c|c|c|c|c|c|c|c|c|c|c|c|}
\hline \multirow{2}{*}{$\begin{array}{l}\text { Mean } \\
\text { dbh } \\
(\mathrm{cm})\end{array}$} & \multicolumn{12}{|c|}{ Trees Per Hectare } \\
\hline & 600 & 800 & 1000 & 1200 & 1400 & 1600 & 1800 & 2000 & 2200 & 2400 & 2600 & 2800 \\
\hline \multicolumn{13}{|c|}{ - } \\
\hline 5 & 200 & 267 & 333 & 400 & 466 & 533 & 600 & 666 & 733 & 800 & 866 & 933 \\
\hline 6 & 267 & 356 & 445 & 534 & 623 & 712 & 801 & 890 & 979 & 1068 & 1157 & 1246 \\
\hline 7 & 341 & 454 & 568 & 682 & 795 & 909 & 1022 & 1136 & 1250 & 1363 & 1477 & 1590 \\
\hline 8 & 421 & 562 & 702 & 842 & 983 & 1123 & 1264 & 1404 & 1544 & 1685 & 1825 & 1966 \\
\hline 9 & 508 & 677 & 846 & 1015 & 1185 & 1354 & 1523 & 1692 & 1861 & 2031 & 2200 & 2369 \\
\hline 10 & 600 & 800 & 1000 & 1200 & 1400 & 1600 & 1800 & 2000 & 2200 & 2400 & 2600 & 2800 \\
\hline 11 & 698 & 931 & 1163 & 1396 & 1628 & 1861 & 2094 & 2326 & 2559 & 2792 & & \\
\hline 12 & 801 & 1068 & 1335 & 1602 & 1869 & 2136 & 2403 & 2671 & & & & \\
\hline 13 & 910 & 1213 & 1516 & 1819 & 2122 & 2426 & 2729 & & & & & \\
\hline 14 & 1023 & 1364 & 1705 & 2046 & 2387 & 2728 & & & & & & \\
\hline 15 & 1141 & 1522 & 1902 & 2283 & 2663 & & & & & & & \\
\hline 16 & 1264 & 1686 & 2107 & 2529 & & & & & & & & \\
\hline 17 & 1392 & 1856 & 2320 & 2784 & & & & & & & & \\
\hline 18 & 1524 & 2032 & 2540 & & & & & & & & & \\
\hline 19 & 1660 & 2214 & 2767 & & & & & & & & & \\
\hline 20 & 1801 & 2401 & & & & & & & & & & \\
\hline 21 & 1946 & 2595 & & & & & & & & & & \\
\hline 22 & 2095 & 2793 & & & & & & & & & & \\
\hline 23 & 2248 & & & & & & & & & & & \\
\hline 24 & 2405 & & & & & & & & & & & \\
\hline 25 & 2566 & & & & & & & & & & & \\
\hline 26 & 2730 & & & & & & & & & & & \\
\hline
\end{tabular}

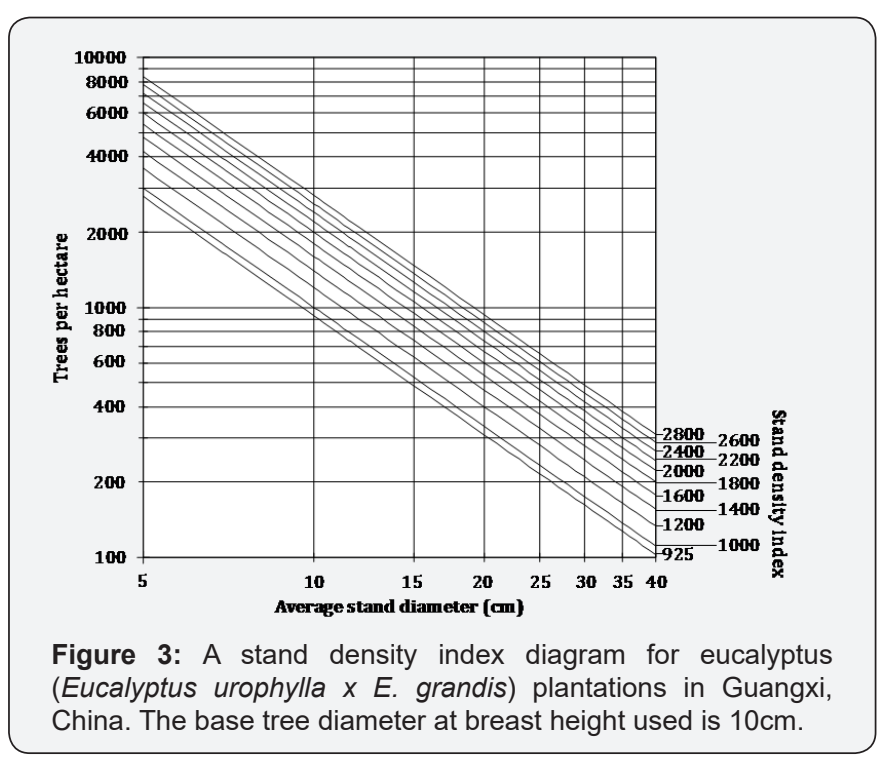

\section{Discussion}

This diagram has much utility for use as it is independent of age and site quality, and allows for direct comparison among plantations. It also provides guidance to the forest manager as to the amount of density they should be maintaining in their plantations. It would be difficult for a manager to know that a plantation with a basal area of $12 \mathrm{~m}^{2} /$ ha and quadratic mean $\mathrm{dbh}$ of $9 \mathrm{~cm}$ to be more dense than a plantation with $18 \mathrm{~m}^{2} /$ ha of basal area and quadratic mean dbh of $23 \mathrm{~cm}$. Maintaining densities below an SDI of 925 would sacrifice total volume yield and underutilize the growing space. On the other hand, maintaining densities near the maximum density would maximize total volume yield, but at the sacrifice of individual tree growth and size.

Data for Eucalyptus urophylla $x$ E. grandis from Liang et al. [27] in Guangxi province and from Han et al. [28] in Guangdong province of south China were plotted on the diagram to examine its usefulness (Figure 4). The Guangxi province data comes from six different plots that were located in a ten-year old plantation. The data from Guangdong represents time series data from two plantations beginning at age one year and ending at age 4 and a half years. 


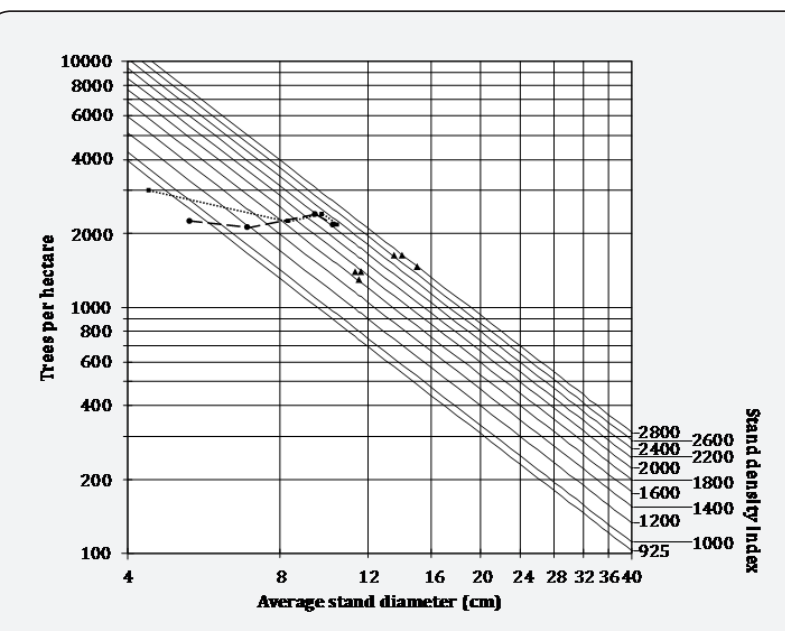

Figure 4: The density management diagram for eucalyptus (Eucalyptus urophylla $\times$ E. grandis) with plotted data from Guangxi [26] and Guangdong [27] provinces in southern China. The Guangxi data reflects six different plantations at age ten years; the Guangdong data reflects a time series for two plantations from age one year through four-and-a-half years.

Figure 4 illustrates different aspects regarding the diagram and development of these eucalyptus stands. First, the diagram is age independent as shown with the Guangxi data. These six plots are all located within the same forest but vary greatly in their density, indicating that it is not a factor of age. Three of the six plots were located on a southwest-facing slope, with an average 26 degree slope, and the remaining three plots on a northeastfacing slope, with average 30 degree slope. The entire plantation was planted at $2 \mathrm{mx} 3 \mathrm{~m}$ spacing with the same fertilizer treatment at the time of planting. By the time the plantation reached an age of ten years, a differentiation in stand density had occurred due to differences in site conditions, with the plots on the northeastfacing slope displaying a lower density. The southwest-facing plots had attained close to the maximum density by age ten years, whereas the northeast-facing plots had only reached 58\%$63 \%$ of maximum density. Apart from looking at comparative densities as with stand density index it is more difficult to see the disparity that exists within this forest, possibly the result of differences in site conditions. Accordingly, the diagram provides managers with more information to make better management decisions.

Second, the Guangdong data demonstrate the density in these stands can increase very rapidly and reach crown closure early due to their rapid growth. In the case of the Guangdong stands they have reached crown closure by the age of two years. By the age of four years they have reached a point where selfthinning begins to become more rapid. The data begin a steeper trajectory of a negative slope, thus indicating the beginning of a more rapid increase in diameter with decrease in trees per hectare. Knowing when these stands begin their self-thinning is helpful in decisions on timing of thinnings, if any, to reach product and volume goals.
Our data did not allow us to get a good estimate of the density when self-thinning begins to occur in these stands. Other studies have used or found estimates that have ranged from $55 \%$ to $63 \%$ of maximum density $[23,25,26,29,30]$. This would place the range of the onset of self-thinning at stand density index of 1540 to 1765 . However, based on the point of where the crown projection ratio begins to decrease in the data and what is seen on the time-series data from Guangdong, it would appear that selfthinning may begin around a stand density index of 2090 to 2200 or $75 \%$ to $79 \%$ of maximum density. As trees begin to experience mortality, canopy gaps begin to occur and the total crown area of the stand is reduced. Accordingly, the total crown projection area is reduced, even though the crowns of the residual trees attempt to fill in these gaps. This does not mean that no mortality has occurred before this point but the causes are more likely to have been a result of pathological or other environmental agents rather than competition. At this stage self-thinning processes begin to occur and mortality rates begin to increase.

Why the self-thinning in these stands begin at such a high density maybe the result of the growth habit of this species and their self-tolerance ability. There are two components of crown closure and development, which are horizontal (crown diameter) and vertical (crown length). These two components are inversely related, in that a decrease in horizontal closure leads to an increase in vertical closure as a result of deeper penetration of sunlight into the canopy [31]. Because of this reciprocating relationship between horizontal and vertical closure, the crown surface area, as defined by crown diameter and crown length, remains relatively constant until stands reach a point of decomposition. Thus, as these eucalyptus trees continue to increase in size after crown closure, because of competition the rate of crown diameter expansion decreases but the crown length continues to increase, maintaining a somewhat constant crown surface area.

Using the allometrical relationship between crown diameter and length [32] the change of crown length with crown diameter was examined with the data:

$$
\ln (l)=-0.3291+1.4957 \ln (d)
$$

Where $\mathrm{l}=$ crown length, $\mathrm{d}=$ crown diameter and $\mathrm{ln}=$ natural logarithm. This model produced an R2 $=0.9567, \mathrm{Sxy}=0.0103$ with 1,916 observations. The fact that the slope is positive and $>1$ indicates that the crown length is increasing at a faster rate than the diameter. Thus, as the radial expansion of the crown slows down as a result of competition, the crown length continues to increase and maintain a constant crown surface.

Eucalyptus in this study displays the typical empirical evidence that suggests they are shade-intolerant, having very sparse crowns and fast growth. In fact, most eucalyptus species are shade-intolerant [33-35]. However, in pure stands many shade-intolerant species display a characteristic of self- 
tolerance, which has been defined as the ability of trees to grow and survive under the stress of intra-specific competition [36]. In other words, shade-intolerant species display a greater tolerance to competition and resistance to self-thinning as compared to existing in mixed stands [36] proposed a measure of self-tolerance as:

$$
\mathrm{S}=(\mathrm{dV} / \mathrm{V}) /(-\mathrm{dN} / \mathrm{N})
$$

Where $S=$ Self-tolerance measure, $d V=$ differential of volume, $\mathrm{V}=$ average tree volume, $\mathrm{dN}=$ differential of tree number, and $\mathrm{N}=$ number of trees. Zeide [36] argued that using the relative values of volume $(\mathrm{dV} / \mathrm{V})$ and of tree number $(-\mathrm{dN} / \mathrm{N})$ eliminated the effect of tree size in self-thinning and provided a measure which depended solely on self-tolerance. The reader is encouraged to examine Zeide [36] for a greater detailed analysis of how this self-tolerance measure is derived

The value of $S$ was calculated for stands in this study, assuming the volume of a cone for tree since local stand volume tables were not available. Dbh was used as the diameter and the height of the tree beginning at $\mathrm{dbh}$ as the length in our calculations to provide an estimate of volume. Accordingly, $\mathrm{S}$ was calculated as 2.6522, which suggests that these eucalyptus stands display a strong self-tolerance. For comparison, of the four southern pine species in the United States that Zeide [36] examined self-tolerance, longleaf pine (Pinus palustris) displayed the greatest selftolerance with $S=1.37$. Thus, it is not unreasonable to conclude that self-thinning in these eucalyptus forests do not occur until very high densities are attained.

The diagram enables managers to establish density control targets dependent upon product goals. Maintaining plantations at or near a stand density index of 2800 would maximize total volume yields but at the expense of producing smaller diameter trees on average. On the other hand, maintaining densities between a stand density index of 925 and 2200 would not maximize the potential volume yield but produce larger diameter trees while still fully utilizing growing space.

The primary assumption in the use of this diagram is that density is adequately represented by SDI and that our approximation of guiding densities (crown closure SDI=925; self-thinning SDI=2090-2200, maximum SDI=2800) are correct. Any stand with a density maintained below crown closure, or SDI of 925, would not make effective use of growing space. Individual tree growth would not be affected by density, and the total volume growth would be proportional to density. Total volume growth would therefore be sacrificed without any additional enhancements to individual tree growth. Stand densities maintained between crown closure and the selfthinning line or lower limit of self-thinning, would basically lie within a zone of full site occupancy and potentially would not experience competition-induced mortality. It is within this zone that maximum tree growth potential can be more closely maintained with the most effective use of growing space.
However, stands with densities maintained within the zone bounded by the line of self-thinning and the maximum density begin to experience more drastic reductions in individual tree growth and higher losses of stand net growth due to higher incidences of mortality. Greater gains are made within this zone of total growth but at the sacrifice of producing smaller trees at the final harvest.

\section{Conclusion}

Knowing at what density to maintain forest stands to reach certain goals is an important but often eluding aspect of forest management. A management diagram for eucalyptus (Eucalyptus urophylla $x$ E. grandis) is presented to provide guidance regarding density manipulation, and the proper density to maintain will depend upon the final product goals. A management strategy may call for high total volume while maintaining trees in a minimal merchantable size class. Maintaining trees at densities just above the density where self-thinning occurs would accomplish such a task while keeping individual trees in a higher vigor category [37]. Another management strategy may call for saw logs or larger veneer logs as a product objective and still maintain full-site utilization, thus requiring higher thinning intensities or wider planting spacings. Maintaining the residual stands between the crown closure and the point of self-thinning would maximize individual tree size without the sacrifice of total volume that would result from under-utilization of growing space. Further research is necessary to verify the critical densities defined in this study as it is recognized that there may be some limitations presented by the data. However, this is the first attempt to provide a quantifiable method that the forest manager has to make better density management decisions.

\section{Acknowledgement}

The author would like to acknowledge and thank the faculty, staff and students at Guangxi Eco-Engineering Vocational and Technical College, Liuzhou, Guangxi, for their cooperation and vital assistance in the data collection. A special acknowledgement is given to Dr. Zhenghong Pang, former President of the college and Dr. Yuhua Tao, Director of International Programs, for their vital assistance in making this project possible. The data collected for this paper was the result of a joint undergraduate research abroad program with Guangxi Eco-Engineering Vocational and Technical College, Liuzhou, Guangxi, P. R. China, and The Ohio State University, Columbus, Ohio, USA.

\section{Conflict of Interest}

The author declares that no economic interest or any other conflict of interest exists with any institution or individuals involved in the collection of data or writing of this paper.

\section{References}

1. RISI (2015) China Timber Supply Outlook. A Special Market Analysis Study. Resource Information Systems Inc. Massachusetts, China.

2. FAO (2015) Global Forest Resources Assessment. Food and Agriculture Organization of the United Nations, Rome, p. 253. 
3. Midgley SJ, Pinyopusarerk K (1996) The role of eucalypts in local development in the emerging economies of China, Vietnam and Thailand. In: Eldridge KG, Crowe MP, Old KM (Eds.), Environmental Management: the role of Eucalyptus and other fast growing species. CSIRO Forestry and Forest Products, Australia pp. 4-10.

4. Turnbull JW (2007) Development of sustainable forestry plantations in China: a review. Australian Centre for International Agricultural Research, Australia.

5. ITTO (2011) Report from China. ITTO Tropical Timber Market Report 16: $12-13$.

6. Chen SX, Chen XF (2013) Technical Problems and Thinking on Eucalypt Plantation Management in China. Eucalypt Science \& Technology 30: 52-59.

7. Liley B (2014) Focus on China: Guigang - Anatomy of a Hardwood Revolution. Presentation to: 'Forest Investment \& Market Outlook' Conference, Australia.

8. Qi SX (2007) Applied Eucalypt cultivation in China. China Forestry Publishing House, Beijing, China.

9. Wu S, Xu J, Li G, Du Z, Lu Z, et al. (2011) Genotypic variation in wood properties and growth traits of Eucalyptus hybrid clones in southern China. New Forests 42(1): 35-503.

10. Newton PF (1997) Stand density management diagrams: Review of their development and utility in stand-level management planning. Forest Ecology and Management. 98(3): 251-265.

11. Newton PF, Lei Y, Zhang SY (2005) Stand-level diameter distribution yield model for black spruce plantations. For Ecol Manage 209(3): 181192.

12. Archibald DJ, Bowling C (1995) Jack pine density management diagram for boreal Ontario. Northeast and Northwest Science and Technology, USA.

13. Jack SB, Long JN (1996) Linkages between silviculture and ecology: an analysis of density management diagrams. Forest Ecology and Management 86: 205-220.

14. Long JN, Shaw JD (2005) A density management diagram for even-aged ponderosa pine stands. Western Journal of Applied Forestry 20(4): 205-215.

15. Dean TJ, Baldwin VCJR (1996) Using a Density-Management Diagram to Develop Thinning Schedules for Loblolly Pine Plantations. Research \& Development Treesearch

16. Cassidy M, Palmer G, Glencross K, Nichols GD, Smith RGB (2012) Stocking and intensity of thinning affect log size and value in Eucalyptus pilularis. Forest Ecology and Management 264: 220-227.

17. Kang B, Liu S, Zhang Z, Jianguo J, Wen Y, et al. (2006) Carbon accumulation and distribution in Pinus massoniana and Cunninghamia lanceolata mixed forest ecosystem in Daqingshan, Guangxi, China. Acta Ecologica Sinica 26(5): 1320-1329.

18. Hua Z, Zhiyun O, Weihua X, Xiaoke W, Hong M, Xiquan L, Yuxin T (2008) Variation of carbon storage by different reforestation types in the hilly red soil region of southern China. For Ecol Manage 255: 1113-1121.
19. SAS Institute Inc (2008) Statistical Analysis System software (version 9.2). Cary NC, USA.

20. Drew JT, Flewelling JW (1977) Some recent Japanese theories of yield-density relationships and their application to Monterey Pine plantations. Forest Science 23(4): 517-534.

21. Drew JT, Flewelling JW (1979) Stand density management: an alternative approach and its application to Douglas-fir plantations. Forest Science 25(3): 518-532.

22.Zeide B (1985) Tolerance and self-tolerance of trees. Forest ecology and Management 13(3-4): 149-166.

23. Williams RA (1994) Stand density management diagram for loblolly pine plantations in north Louisiana. South J Appl For 18(1): 40-45.

24. Williams RA (2003) Use of stand density index as an alternative to stocking percent in upland hardwoods. North J Appl For 20(4): 1-6.

25. Long JN (1985) A practical Approach to Density Management. Forest Chronicle 61(1): 23-27.

26. McCarter JB, Long JN (1986) A lodgepole pine density management diagram. West J Appl 1: 6-11.

27. Liang H, Luo H, Wen Y, Yang Y, Yang J (2010) Effects of eucalypt plantation replacing Masson pine nature forest on the carbon accumulation of forest ecosystems. Acta Agriculturae Universitatis Jiangxiensis. 32(6): 1168-1174.

28. Han F, Zhou Q, Chen S, Chen W, Li T, Wu Z, Jian M (2010) Study on biomass and energy of two different-aged eucalyptus stands. Forest Research 23(5): 690-696.

29. Hibbs DE (1987) The self-thinning rule and red alder management. Forest Ecology and Management 18: 273-281.

30. John SD, James LN (2007) A density management diagram for longleaf pine stands with application to red-cockaded woodpecker habitat. South J Appl 31(1): 28-38.

31. Zeide B (1991) Self-thinning and stand density. For Sci 37(2): 517-523.

32. Huxley JS (1932) Problems of relative growth. The Dial Press, USA, p. 276.

33. King DA (1997) The functional significance of leaf angle in Eucalyptus. Australian Journal of Botany 45(4): 619-639.

34. Bauhus J, van Winden AP, Nicotra AB (2004) Above ground interactions and productivity in mixed-species plantations of Acacia mearnsii and Eucalyptus globulus. Can J For Res 34(3): 686-694.

35. Forrester DI, Medhurst JL, Wood M, Beadle CL, Valencia JC (2010) Growth and physiological responses to silviculture for producing solidwood products from Eucalyptus plantations: An Australian perspective. Forest Ecology and Management 259: 1819-1835.

36. Zeide B (1987) Analysis of the $3 / 2$ power law of self-thinning. For Sci 33(2): 517-537.

37. Westveld M (1954) A budworm vigor-resistance classification for spruce and balsam fir. J For 52(1): 11-24. 


\section{Your next submission with Juniper Publishers will reach you the below assets}

- Quality Editorial service

- Swift Peer Review

- Reprints availability

- E-prints Service

- Manuscript Podcast for convenient understanding

- Global attainment for your research

- Manuscript accessibility in different formats ( Pdf, E-pub, Full Text, Audio)

- Unceasing customer service

Track the below URL for one-step submission https://juniperpublishers.com/online-submission.php 